九州大学学術情報リポジトリ

Kyushu University Institutional Repository

\title{
A Revision of the Genus Tetragnatha Latreille (Araneae, Tetragnathidae) of Asia, Part I
}

Okuma, Chiyoko

Entomological Laboratory, Faculty of Agriculture, Kyushu University

https://doi.org/10.5109/23876

出版情報：九州大学大学院農学研究院紀要. 32 (3/4)，pp. 165-181，1988-03. Kyushu University バージョン：

権利関係: 


\title{
A Revision of the Genus Tetragnatha Latreille (Araneae, Tetragnathidae) of Asia, Part I*
}

\author{
Chiyoko Okuma \\ Entomological Laboratory, Faculty of Agriculture, \\ Kyushu University, Fukuoka 812 \\ (Received September 24. 1987)
}

\begin{abstract}
The spiders of Asian Tetragnatha are revised based on the specimens from Nepal, Bangladesh, Sri Lanka, Thailand, Malaysia, Indonesia, Philippines, Hong Kong, Taiwan, Korea and Japan. Twenty-nine species are recognized, which are divided into two major species groups, A and B. This paper (Part I) reports the species of the major group A. New records of distribution are as follows : T.javana from Nepal and Bangladesh and T. ceylonica from Philippines.
\end{abstract}

This paper reports the result of my systematic study on the genus Tetragnath Latreille of Asia. Twenty nine species in all, including nine species already described by me, are recognized from Nepal, Bangladesh, Sri Lanka, Thailand, Malaysia, Indonesia, Philippines, Hong Kong, Taiwan, Korea and Japan. Illustrations of the important characters of all the species are given, and keys are provided for the species groups and species. Tetragnath may be divided into two major species groups, which are tentatively called A and B groups. These groups may eventually be recognized as subgenera. The present paper (Part I) includeds 9 species which belong to the major species group A.

For abbreviations of the cheliceral aremature see Okuma (1987).

Before going further, I wish to express my hearty thanks to Prof. Y. Hirashima of Kyushu University for helpful suggestions and encouragement throughout the course of my study. I am grateful for my colleagues listed below who offered me vluable specimens for the present study : Mr. Joseph Koh (Singapore), Dr. J. Martens (Univ. Mainz, Germany), Dr. JoAnn M. Tenorio (Bishop Mus., Honolulu), prof. Yau-I Chu (National Taiwan Univ., Taiwan), Mr. S. Asama (Chiba Pref.), Mr. Y. Chikuni (Nagano Pref.), Dr. T. Goto (Kyushu Univ.), Dr. T. Kamura (Kyoto Pref. Univ.), Mr. H. Makihara (Forestry and Forest Products Res. Ins., Tsukuba), Dr. Y. Nishikawa (Ohtemon Gakuin Univ., Osaka), Mr. K. Ohara (Tokushima Pref.), Dr. H. Ono (Nat. Sci. Mus., Tokyo), Mr. T. Sasaki (Univ. of the Ryukyus), Mr. A. Tanigawa (Yokohama City), Dr. K. Umeya (National Agr. Res. Center, Tsukuba) and Dr. T. Yaginuma (Ohtemon Gakuin Univ.). And I am also grateful to Assoc. Prof. K. Morimoto, Dr. K. Ogata and Dr. 0. Tadauchi of Kyushu University for their kindness in many ways.

* Contribution from the Entomological Laboratory, Faculty of Agriculture, Kyushu University, Fukuoka (Ser. 3, No. 256). 
Grouping of the species

The species of Tetragnatha may be divided into two major groups, A and B, accoding to the conductor of male palpus (Levi, 1981). In the group A, it is plicate laterally, while in the group B, it is entire. The major species groups may be divided further into (minor) species-groups. The group A includes the bituberculata, caudicula, extensa, praedonia and shinanoensis species-groups. The group B includes the cylindrica, lauta, mandibulata, maxillosa, rubriventris, serra, squamata and striata speciesgroups.

\section{KEY TO THE SPECIES-GROUPS OF ASIAN TETRAGNATHA} BASED ON THE MALE

1 Conductor with pleats laterally

- Conductor without pleats laterally......

2 Lateral eyes more separated than median eyes ; abdomen with a tail overhanging spinnerets ................................................ caugiculu-group

Lateral eyes as close as or closer than median eyes ; abdomen not as

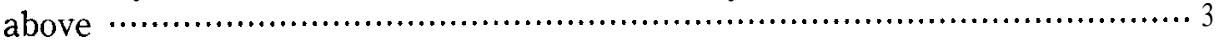

3 Posterior row of eyes wider than anterior row of eyes $\cdots \cdots \cdots \cdots \cdots \cdots \cdots \cdots \cdots \cdots \cdots \cdots \cdots$

- Two rows of eyes equal or subequal in width

4 Lateral eyes closer than median eyes and situated on a tubercle

Lateral eyes slightly closer than median eyes and situated on each tubercle praedonia-group

5 Conductor bifurcated at tip hinanoensis-group

- Conductor not bifurcated at tip extensa-group

$6 \quad$ Fang with an outer cusp near base ; (Gl) robust squamata-group Fang usualy without outer cusp near base

7 Posterior row of eyes evidently narrower than anterior row of eyes $\cdots \cdots \cdots \cdots \cdots$ Posterior row of eyes not narrower than anterior row of eyes $\ldots \ldots \ldots \ldots \ldots \ldots \ldots . .6$

8 Chelicera as long as or longer than carapace rubriventris-group Chelicera shorter than carapace ; lateral eyes more separated than median eyes striata-group

9 Abdomen more than 6 times as long as broad ….................. cylindrica-group

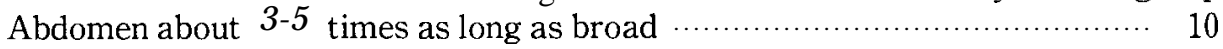

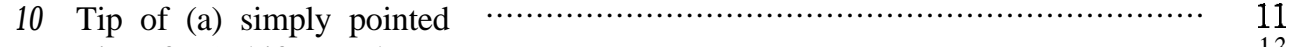
Tip of (a) bifurcated …......................................................... 13

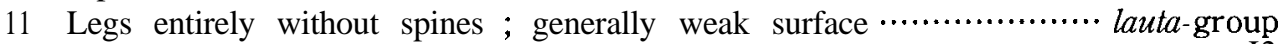

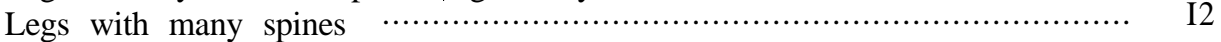

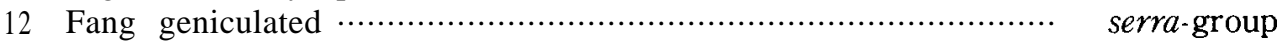

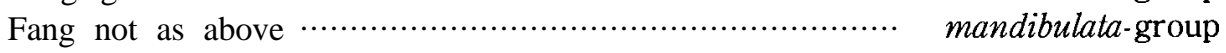

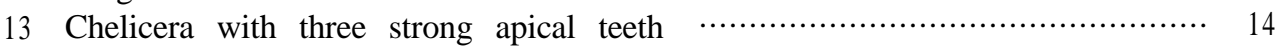
Chelicera not as above …...................................... maxillosa-group

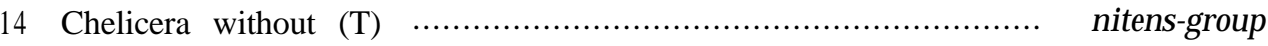

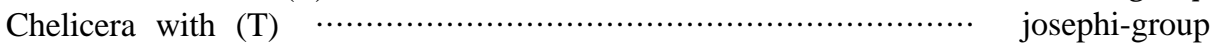




\section{The caudicula-group}

Diagnosis. Posterior row of eyes evidently narrower than anterior row of eyes ; lateral eyes more separated than median eyes ; abdomen with a tail overhanging spinnerets.

\section{KEY TO THE SPECIES}

1 Spinnerets situated beyond the middle of abdomen caudicula

- Spinnerets situated about the middle of abdomen ... . - javana

\section{Tetragnatha caudicula (Karsch, 1879)}

(Fig. 1, Table 1)

Eugnatha caudicula Karsch, 1879, Verh. Nat. Ver. Rheinl. Westf., $36: 66$; Simon, 1881, Arachn. de France, 5 (1): 7.

Tetragnatha caudicula Boesenberg und Strand, 1906, Abh. Senckenbg. Ges., 30 (1-2) : 179 ; Paik, 1957, Korean J. Biol., $2: 43$; Yaginuma, 1960, Spiders of Japan in Colour: 74.

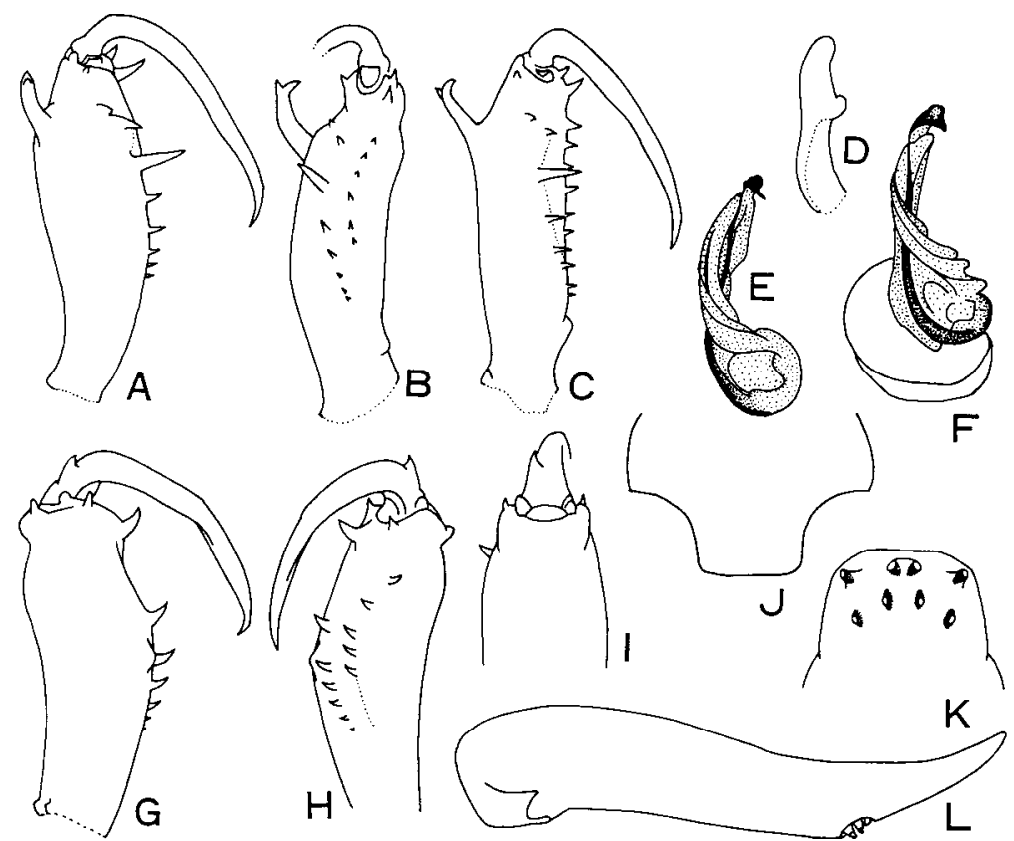

Fig. 1. Tetragnatha caudicula (Karsch). A : Left chelicera of male, upper view. B : Ditto, inner view. C: Ditto, upper inner view. D: Paracymbium of male. E and F: Conductor and embolus of male. G : Left chelicera of female, upper view. H : Ditto, inner view. I : Ditto, lateral view. J : Genital fold of female. K : Eye group of female. $\mathrm{L}$ : Abdomen of female, lateral view. 
Table 1. Tetragnatha caudicula (Karsch). Relative lengths of total legs and femora.

\begin{tabular}{|c|c|c|c|c|c|c|c|c|c|c|c|}
\hline Locality & & \multirow[t]{2}{*}{$n$} & $\begin{array}{l}\text { length of } \\
\text { meants.d. }\end{array}$ & $\begin{array}{c}\text { 1st leqs } \\
r \text { a } \mathrm{d}\end{array}$ & \multirow[t]{2}{*}{$\begin{array}{c}\text { 1st leqs } \\
\text { ratio- }\end{array}$} & \multicolumn{2}{|c|}{$\begin{array}{l}\text { 2nd legs } \\
\text { ratio (r) }\end{array}$} & \multicolumn{2}{|c|}{$\begin{array}{l}3 \text { rd legs } \\
\text { ratio (r) }\end{array}$} & \multicolumn{2}{|c|}{$\begin{array}{l}\text { 4th legs } \\
\text { ratio (r) }\end{array}$} \\
\hline (Legs) & & & & & & & & & & & \\
\hline Hokkaido & d & 1 & 21.90 & & 100 & 62 & & 28 & & 63 & \\
\hline Kanagawa & $\delta$ & 2 & 21.78 & $20.30-23.25$ & & 60 & & 27 & & 62 & \\
\hline Tottori & 0 & 1 & 26.50 & & & 61 & & 28 & & 62 & \\
\hline Tokushima & 8 & 4 & $21.31 \mathrm{f} 4.08$ & $16.40-25.30$ & & 60 & $(0.998)$ & 27 & $(0.999)$ & 611 & 10.999 \\
\hline Ryukyu Is. & $\delta$ & 5 & $22.04 \mathrm{f} 2.77$ & $19.15-26.65$ & & 59 & $(0.996)$ & 27 & $(0.980)$ & 62 & 10.999 \\
\hline KOREA & 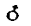 & 3 & 24.1 af 1.33 & $22.70-25.25$ & & 61 & $(0.992)$ & 27 & $(0.969)$ & $61)$ & 10.988 \\
\hline Hokkaido & 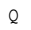 & 2 & 18.78 & $15.25-22.30$ & & 61 & & 29 & & 64 & \\
\hline Kanagawa & 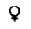 & 2 & 22.68 & $20.00-25.35$ & & 61 & & 28 & & 62 & \\
\hline Tokushima & $Q$ & 4 & $21.55 \mathrm{f} 2.20$ & $18.85-23.80$ & & 60 & $(0.986)$ & 28 & $(0.883)$ & 64 & $(0.980)$ \\
\hline Ryukyu Is. & $Q$ & 2 & 20.18 & $19.50-20.85$ & & 59 & & 28 & & 67 & \\
\hline KOREA & $\varnothing$ & 9 & $21.67 f 2.02$ & $18.50-24.45$ & & 61 & $(0.978)$ & 28 & $(0.980)$ & 63 & $(0.977)$ \\
\hline Hokkaido & o & 1 & 6.30 & & & 67 & & 34 & & 77 & \\
\hline Kanagawa & $d$ & 2 & 6.10 & $5.80-6.40$ & & 67 & & 34 & & 75 & \\
\hline Tottori & 8 & 1 & 7.40 & & & 68 & & 35 & & 76 & \\
\hline Tokushima & d & 4 & $5.90 f 1.07$ & $4.60-7.00$ & & 66 & $(0.999)$ & 34 & $(0.999)$ & 751 & $(0.998)$ \\
\hline Ryukyu Is. & o & 5 & $6.23 f 0.79$ & $5.35-7.50$ & & 65 & $(0.993)$ & 34 & $(0.957)$ & $75 i$ & $(0.999)$ \\
\hline KOREA & $\delta$ & 3 & $6.72 \mathrm{f} 0.32$ & $6.35-6.90$ & & 68 & $(0.993)$ & 35 & $j$ & 75 ( & $(0.945)$ \\
\hline Hokkaido & $Q$ & 2 & $5.38 \mathrm{f} 1.52$ & $4.30-6.45$ & & 65 & & 34 & & 78 & \\
\hline Kanagawa & $Q$ & 2 & $6.50 f 1.13$ & $5.70-7.30$ & & 65 & & 34 & & 75 & \\
\hline Tokushima & 8 & 4 & $6.20 \pm 0.72$ & $5.30-6.95$ & & 65 & $(0.990)$ & 34 & $(0.885)$ & $77 \quad($ & $(0.991)$ \\
\hline Ryukyu Is. & $Q$ & 2 & $5.85 \mathrm{f} 0.21$ & $5.70-6.00$ & & 65 & & 34 & & 81 & \\
\hline KOREA & $Q$ & 9 & $6.21 \mathrm{f} 0.62$ & $5.20-7.05$ & & 67 & $(0.978)$ & 34 & $(0.974)$ & $77 \quad($ & $(0.975)$ \\
\hline
\end{tabular}

$\mathbf{n}=$ Number of specimens.

$\mathbf{r}=$ coefficient of correlation.

Male. Body length, exclusive of chelicerae $6.0-11.0 \mathrm{~mm}$; carapacial length $1.6-$ $3.0 \mathrm{~mm}$, width LO-1.3 mm ; abdominal length 4.5-8.0 mm, width 0.6-1.0 mm ; cheliceral length 1.1-2.0 mm.

Eyes. Anterior row of eyes occupying full width of head ; posterior row of eyes evidently narrower than anterior one; viewed from above, anterior row nearly straight, posterior row somewhat strongly recurved, so that lateral eyes more separated than median eyes.

Chelicerae. Basal segment about 0.7 times as long as carapace ; (a) large, bifurcated at tip ; $(\mathrm{t})$ and (sl) somewhat directed backward ; (T) large, (rsu) about 5 in number ; $(\mathrm{AXl})$ and $(\mathrm{Gl})$ present, (rsl) about 6 in number ; fang unarmed.

Legs. Leg formula 1. 4. 2.3 ; all legs with spines, first femur with about 10 spines ; relative lengths of legs as shown in Table 1.

Palpi. Paracymbium bluntly rounded at tip ; conductor twisted at the middle and terminating in a characteristic form as shown in Fig. 1, E and F.

Abdomen. Long, inclusive of the tail, about 6-8 times as long as broad.

Color in alcohol. Legs, carapace and chelicerae generally light brown ; maxillae, lip and sternum somewhat dusky brown; abdomen covered with dusky silvery spangles dorsally, somewhat dusky brown ventrally.

Female. Body length, exclusive of chelicerae $8.0-15.0 \mathrm{~mm}$; carapacial length 2.3-3.0 mm, width 1.1-1.8 mm ; abdominal length $5.8-12.0 \mathrm{~mm}$, width $1.3-2.0 \mathrm{~mm}$; cheliceral length 1.0-1.8 mm.

Eyes. Nearly as in male.

Chelicerae. Basal segment 0.4-0.6 times as long as carapace, outerside near apex and middle of dorsurn somewhat swollen and with a tubercle each; (AXu) and (Gu) present, (rsu) about 5 in number ; (Gl) present, (rsl) about 5 in number ; fang with (EX) near base.

Legs. Nearly as in male ; relative lengths of legs as shown in Table. 1. 
Abdomen. Long, about 4.5-6.0 times as long as broad.

Color in alcohol. Similar to male.

Specimens examined : KOREA :3ァ,9우, Paddy field, Suweon, 18. VII - 4. VIII. 1975, N. Hokyo et al. JAPAN : 48 specimens from Hokkaido (Ashoro), Ibaragi (Tsukuba), Tokyo (Hachiouzi), Tochigi (Nikko, Chuzenji-kohan), Kanagawa (Hiratsuka), Tottori (Mt. Daisen), Tokushima (Kamiakui-cho), Ohita (Odanoike, Yuhuin-cho), Amami-oshima Is. (Mt. Yuwan), Ishigaki Is. (Arakawa), Iriomote Is., Minamidaitozima.

Distribution : Japan and Korea.

Tetragnatha javana (Thorell, 1890)

(Fig. 2, Table 2)

Eucta javana Thorell, 1890, Ann. Mus. Civ. Genova, $28: 236$.

Tetragnatha (Eucta) javana: Okuma, 1968, Mushi,42: 100; Okuma, 1970, Mushi, $44: 73$.

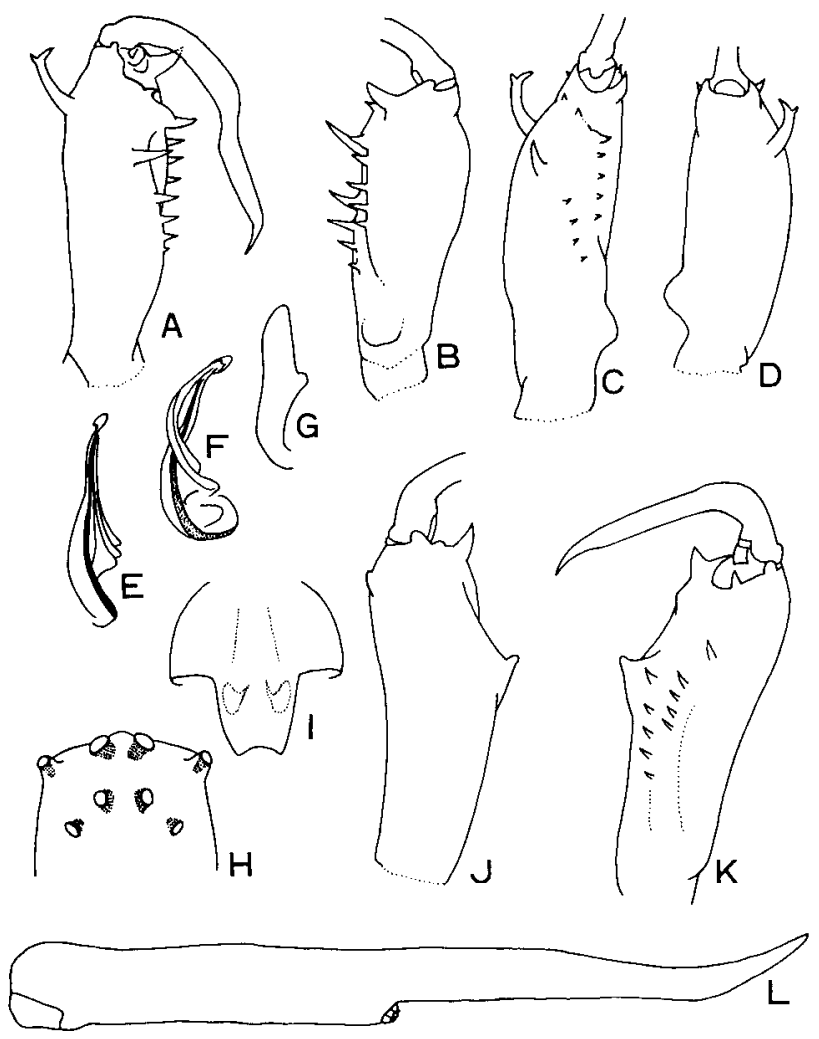

Fig. 2. Tetragnatha javana (Thorell). A : Left chelicera of male, upper view. B: Ditto, lower view. C : Ditto, inner view. D : Ditto, lateral view. E and F : Conductor and embolus of male. $\mathrm{G}$ : Paracymbium of male. H : Eye group of female. I : Genital fold of female. J : Left chelicera of female, lateral view. K : Ditto, inner view, L : Abdomen of female, lateral view. (After Okuma, 1984). 


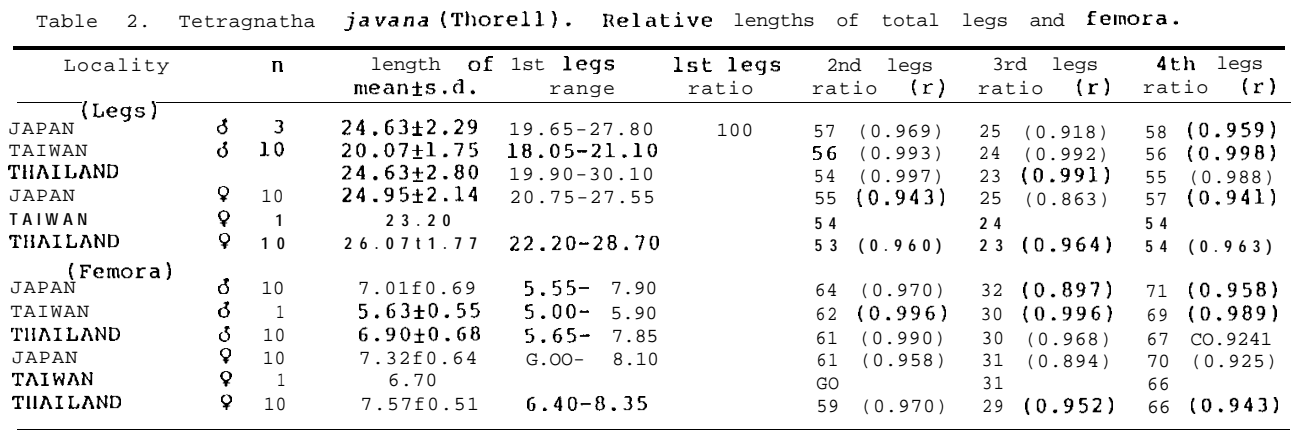

Tetragnatha javana : Okuma, 1984, Esakia, (22): 88.

Additional specimens : NEPAL :1 $\sigma^{7}$, Chauni 1300-1400, Kathmandu Valley, end of July, 1973, J. Martens. BANGLADESH : 126, 13우, Central Bangladesh, VIII-IX. 1978, H. D. Catring; $2 ð^{ð}, 3$ 우, Mymensingh, 12. IV. 1987, Y. Hirashima. JAPAN : 40 specimens from Iriomote Is. (Sonai), Ishigaki Is. (Kabira and Nakura), Okinawa (Hachi), Amami-Oshima (Yakkachi, Naze and Taira).

Distribution : Africa, Nepal (new record), Bangladesh (new record), SE Asia and Japan (the Ryukyus up to Amami-Oshima).

Note : This species is common in paddy fields of SE Asia ; body length of male 8.0-12.0 mm, female $10.0-18.0 \mathrm{~mm}$.

\section{The bituberculata-group}

Diagnosis. Posterior row of eyes wider than anterior row of eyes ; lateral eyes closer than median eyes, and situated on a tubercle ; anterior median eyes closer than posterior median eyes ; male chelicerae with (a), (t), (sl) and (T) ; female chelicera with (e) between $(\mathrm{Gu})$ and $(\mathrm{T})$.

Tetragnatha bituberculata, an Australasian species, does not occur in Asia.

\section{KEY TO THE SPECIES}

1 Male paracymbium with tip pointed, and subapical margin serrate $\cdots \cdots$ ceylonica

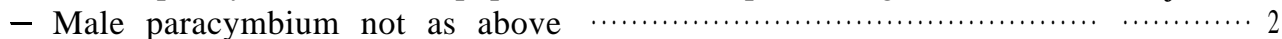

2 Male paracymbium with tip rounded $\ldots \ldots \ldots \ldots \ldots \ldots \ldots \ldots \ldots \ldots \ldots \ldots \ldots$ makiharai

- Male paracymbium with tip rather squared $\ldots \ldots \ldots \ldots \ldots \ldots \ldots \ldots \ldots$ boninensis

\section{Tetragnatha ceylonica Cambridge, 1869}

(Fig. 3, Table 3)

Tetragnatha ceylonica Cambridge, 1869, Journ. Linn. Soc. Zool., 10 : 394 ; Okuma, 1987, Esakia, (25): 48.

Additional specimens : PHILIPPINES :1우, Mindanao, 12. VIII. 1985, Y. Nishikawa (NSMT-Ar. 1127) ; 1 ㄱ, 1우, Mindanao, 13. VIII. 1985, Y. Nishikawa (NSMT-Ar. 1128) ; 우, Palawan Is., 1. IX. 1985, M. Sakai (NSMT-Ar. 1130) ; 1 young, Palawan Is., 


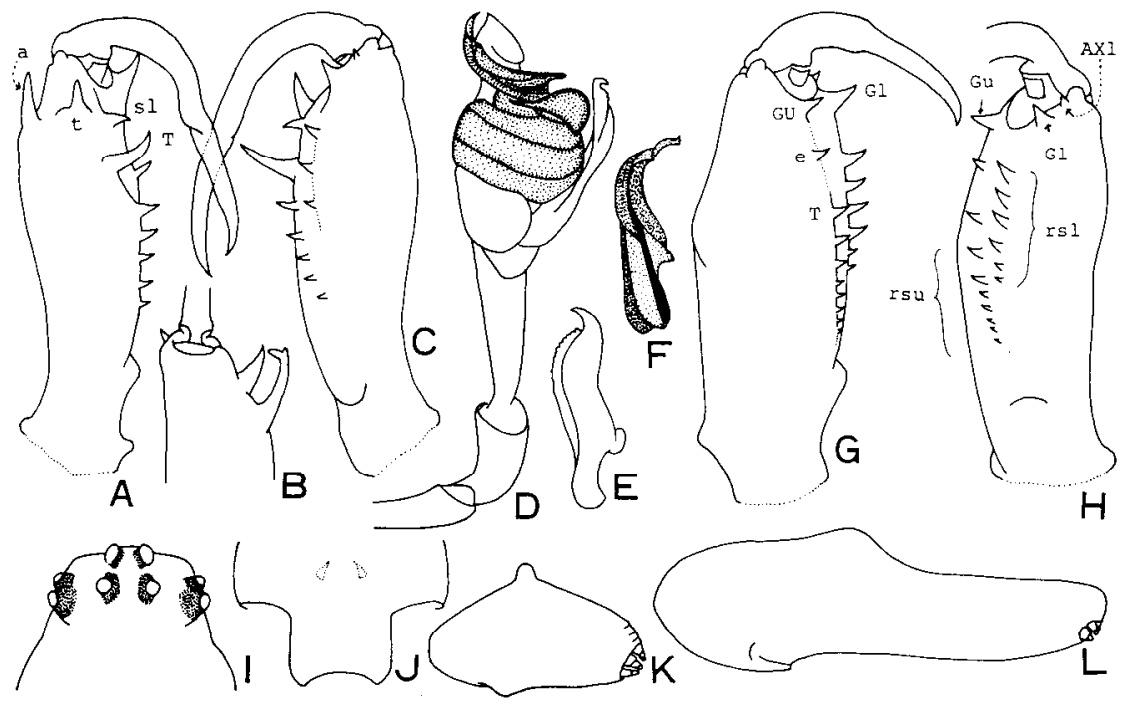

Fig. 3. Tetragnatha ceylonica Cambridge. A : Left chelicera of male, upper view. B : Ditto, lateral view. C : Ditto, lower view. D : Left palpus of male. E : Paracymbium of male. F : Conductor and embolus of male. G : Lift chelicera of female, upper view. H : Ditto, lower inner view. I : Eye group of female. J : Genital fold of female. K: Abdomen of the young of very early stage, lateral view. $L$ : A bdomen of female, lateral view.

Table 3. Tetragnatha ceylonica Cambridge. Relative lengths of total legs and femora.

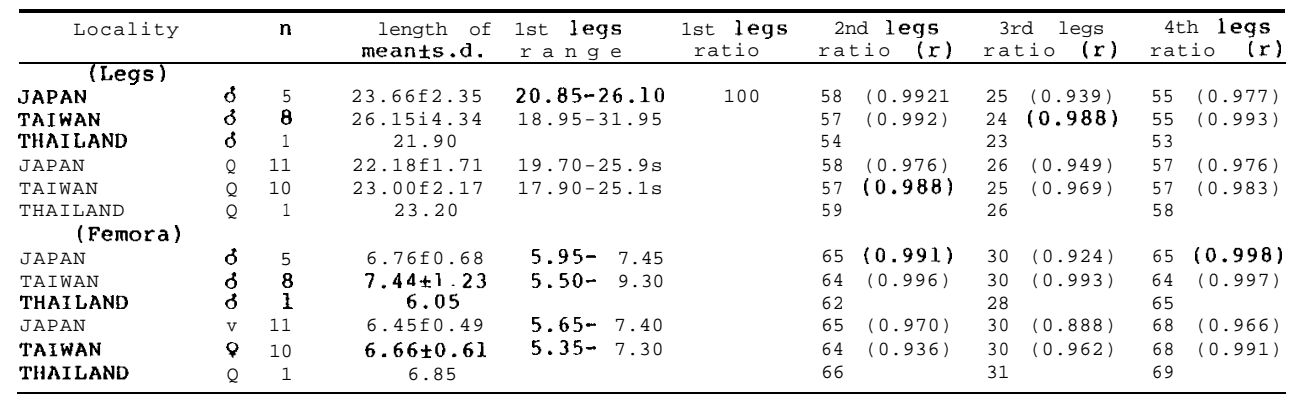

26. VIII. 1985, M. Tomokuni (NSMT-Ar. 1129). THAILAND: 107, Kaoyai National Park, 26, 27. XII. 1977, T. Irie ;5우, Chang mai, 11. XII. 1985. T. Sasaki ;2 우, Khoscidoo, Chanthaburi, 20. XII. 1985, T. Sasaki ; 1 young, Kaoyai National Park, 21. VI. 1986, T. Sasaki ; 1 우, Bangkok, 13. II. 1986, T. Sasaki. TAIWAN : 32 specimens from (Tachi, Ilan Hsien), (Lienhuachih, Nanto Hsien), (Wulai, Taipei Hsien), (Hungyehwenchuan, Hualien Hsien), (Chihpenwanchuan, Taitung Hsien), (Shihtoushan, Hsinchu Hsien), (Lanhsu, Taitung Hsien). JAPAN : Yonaguni, Ishigaki Is. (Mt. Omoto), Iriomote Is. (Funaura, Mt. Goza and Ohara).

Distribution : New Guinea, Thailand, Philippines (new record), Taiwan and Japan 
(the Ryukyus up to Okinawa).

Body length : male 6.3-11.0 mm, female 7.5-12.0 mm.

Tetragnatha makiharai Okuma, 1977

(Fig. 4, Table 4)

Tetragnathu makiharai Okuma, 1977, Acta Arachnol., $27: 27$.

Additional specimens : JAPAN : 22 specimens from Okinawa (Nago, Oku, Hen-

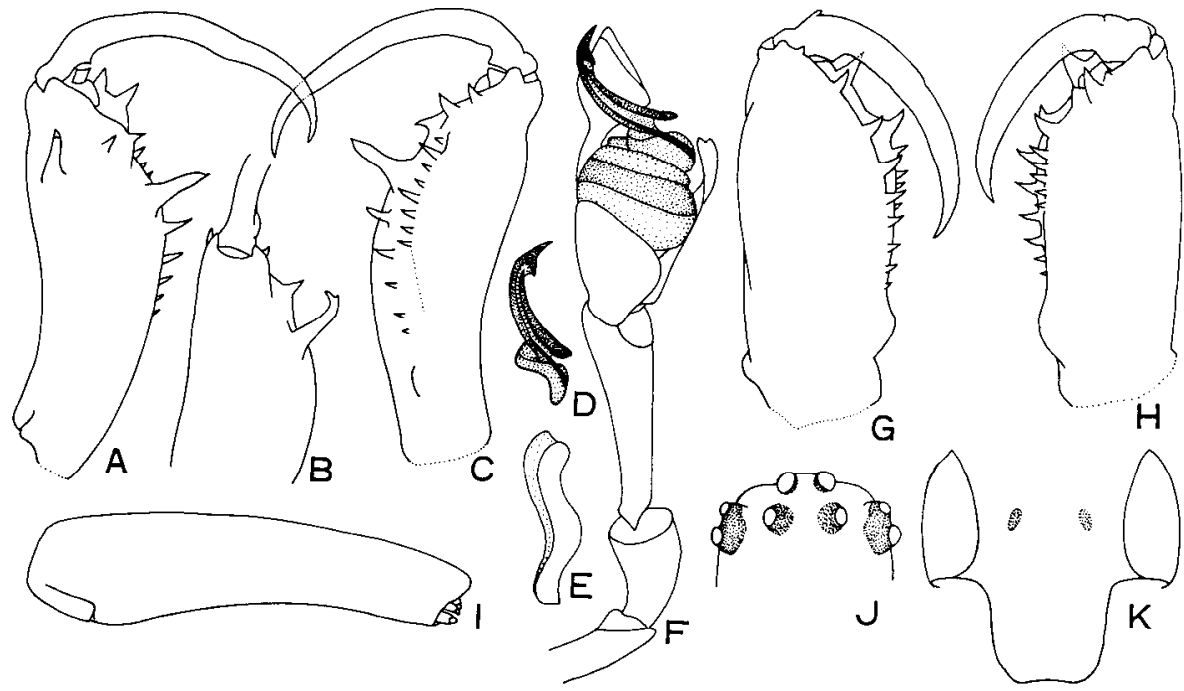

Fig. 4. Tetragnatha makiharai Okuma. A : Left chelicera of male, upper view. B : Ditto, lateral view. C: Ditto, lower view. D: Conductor and embolus of male. E: Paracymbium of male, F : Left palpus of male. G : Left chelicera of female, upper view. H : Ditto, lower view, I : Abdomen of male, lateral view. J : Eye group of male. $\mathrm{K}$ : Genital fold of female.

Table 4. Tetragnatha makiharai $0 \mathrm{k} \mathrm{u} \mathrm{ma.} \mathrm{Relative} \mathrm{lengths} \mathrm{of} \mathrm{total} \mathrm{legs} \mathrm{and} \mathrm{femora.}$

\begin{tabular}{|c|c|c|c|c|c|c|c|c|c|c|c|}
\hline \multicolumn{2}{|l|}{ Locality } & \multirow{2}{*}{$\begin{array}{l}\text { n } \\
4\end{array}$} & \multirow{2}{*}{$\begin{array}{l}\begin{array}{c}\text { length of } \\
\text { meants.d. }\end{array} \\
24.99 \pm 1.54\end{array}$} & \multirow{2}{*}{$\begin{array}{c}\text { 1st } \begin{array}{c}\text { legs } \\
\text { range }\end{array} \\
23.54-27.15\end{array}$} & \multirow{2}{*}{$\begin{array}{c}\text { 1st legs } \\
\text { ratio } \\
100\end{array}$} & \multicolumn{2}{|c|}{$\begin{array}{l}\text { 2nd legs } \\
\text { ratio ( }\end{array}$} & \multicolumn{2}{|c|}{$\begin{array}{l}\text { 3rd legs } \\
\text { ratio (r) }\end{array}$} & \multicolumn{2}{|c|}{$\begin{array}{l}\text { 4th legs } \\
\text { ratio (r) }\end{array}$} \\
\hline $\begin{array}{c}\text { (Legs) } \\
\text { Tsushima }\end{array}$ & 3 & & & & & 55 & $(0.993)$ & 2410 & $(0.981)$ & 511 & $(0.981)$ \\
\hline Anami-oshima & 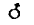 & 4 & $23.11 \mathrm{f} 1.64$ & $21.20-25.20$ & & 56 & $(0.923)$ & $25 i$ & $(0.985)$ & 54 & $(0.919)$ \\
\hline Okinawa Is. & 8 & 14 & $25.77 \mathrm{f} 2.27$ & $21.70-28.75$ & & 56 & $(0.982)$ & 24 & $(0.965)$ & 531 & $(0.987)$ \\
\hline Kuma Is. & $d$ & 2 & 27.58 & $27.20-27.95$ & & 57 & & 25 & & 54 & \\
\hline Tsushima & $q$ & 7 & $23.84 f 1.44$ & $21.65-26.10$ & & 55 & 10.95 & $24 \quad($ & $(0.857)$ & 52( & $(0.957)$ \\
\hline Amami-oshima & 9 & 5 & $23.03 f 0.78$ & $22.20-23.90$ & & 56 & $(0.887)$ & 26 & & $54 i$ & 7831 \\
\hline Okinawa Is. & 8 & 22 & $23.75 f 1.74$ & $20.40-26.70$ & & 55 & $(0.885)$ & 25 & $(0.833)$ & $54 i$ & $(0.892)$ \\
\hline Kume Is. & 9 & 2 & 22.75 & $21.85-23.65$ & & 53 & & 23 & & 52 & \\
\hline $\begin{array}{l}\text { (Femora) } \\
\text { Tsushlma Is. }\end{array}$ & $\delta$ & 4 & $6.96 \mp 0.46$ & $6.50-7.60$ & & 61 & $(0.971)$ & $28 \quad($ & $(0.973)$ & 601 & $(0.977)$ \\
\hline Anami-oshima & $\delta$ & 4 & $6.48+0.41$ & $6.00-7.00$ & & 64 & $(0.865)$ & 301 & $(0.997)$ & 641 & $(0.965)$ \\
\hline Okinawa Is. & $\delta$ & 14 & $7.25 f 0.65$ & $6.15-8.20$ & & 62 & $(0.977)$ & $29 \quad($ & $(0.915)$ & $\begin{array}{l}631 \\
63\end{array}$ & $(0.956)$ \\
\hline Kevureins. Is. & 里 & 2 & 6.8450839 & $6.20-7.85$ & & $6 B$ & $(0.952)$ & 281 & $(0.726)$ & 621 & $(0.978)$ \\
\hline Amami-oshima & Q & 5 & $6.70 f 0.23$ & $6.50-7.00$ & & 63 & $(0.944)$ & $30 \quad($ & $(0.899)$ & 651 & $(0.812)$ \\
\hline Okinawa Is. & $Q$ & 22 & $6.98 \mp 0.46$ & $6.15-7.80$ & & 61 & $(0.981)$ & 281 & $(0.860)$ & 64 & $(0.898)$ \\
\hline Kume IS. & 甲 & 2 & 6.60 & $6.40-6.80$ & & 59 & & 27 & & 63 & \\
\hline
\end{tabular}


nogi and Yonaha dake), Kumezima Is., Tsushima Is. (Mt. Oboshi yama, Minemura).

Distribution : Japan (the Ryukyus and Tsushima Is).

Body length : male $6.5-8.6 \mathrm{~mm}$, female $8.2-11.0 \mathrm{~mm}$.

Tetragnatha boninensis Okuma, 1981

(Fig. 5, Table 5)

Tetragnatha boninensis Okuma, 1981, Esakia, (17): 141.

Additional specimens : 76, 3ㅇ, Hahazima, Ogasawara Is., 1-7. VII. 1986, H. Makihara.

Distribution : Japan (the Ogasawara Is.).

Body length : male 5.2-6.6 mm, female $6.2-6.5 \mathrm{~mm}$.
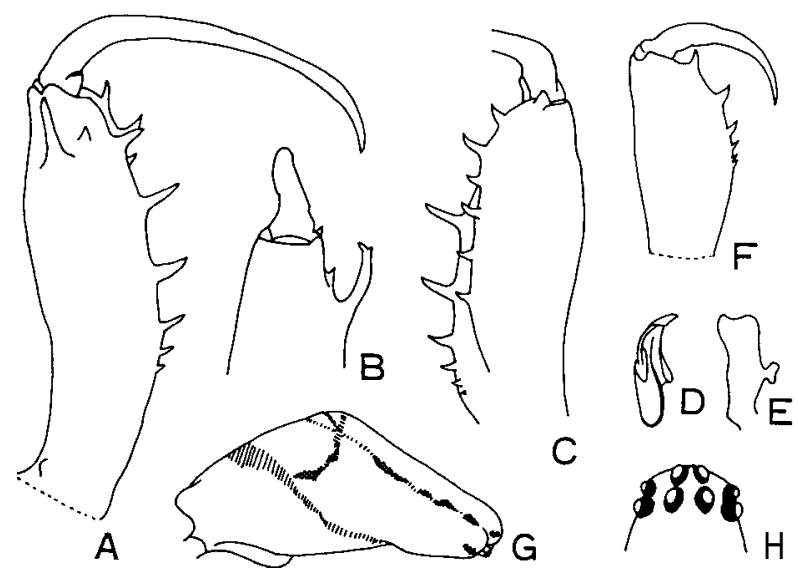

Fig. 5. Tetragnatha boninensis Okuma. A : Left chelicera of male, upper view. B : Ditto, lateral view. C : Ditto, lower view. D : Distal portion of conductor and embolus of male. E : Paracymbium of male. F : Left chelicera of female, upper view. G : Abdomen of female, lateral view. $\mathrm{H}$ : Eye group of female. (After Okuma, 1981).

\begin{tabular}{|c|c|c|c|c|c|c|c|c|c|c|c|}
\hline Locality & & $n$ & $\begin{array}{l}\text { length of } \\
\text { meants.d. }\end{array}$ & $\begin{array}{c}\text { 1st legs } \\
\text { range }\end{array}$ & $\begin{array}{l}\text { 1st legs } \\
\text { ratio }\end{array}$ & $\begin{array}{l}\text { 2nd } \\
\text { ratio }\end{array}$ & $\begin{array}{r}\text { legs } \\
\text { (r) }\end{array}$ & $\begin{array}{r}3 \text { rd } \\
\text { rati }\end{array}$ & $\begin{array}{l}\text { legs } \\
\text { (r) }\end{array}$ & $\begin{array}{c}4 \text { th } \\
\text { ratio }\end{array}$ & $\begin{array}{c}\text { legs } \\
\circ(\mathrm{r})\end{array}$ \\
\hline $\begin{array}{l}\text { (Legs) } \\
\text { ogasawara Is. } \\
\text { ogasawara Is. }\end{array}$ & $\begin{array}{l}0 \\
9\end{array}$ & $\begin{array}{l}4 \\
4\end{array}$ & $\begin{array}{l}16.85 t 2.27 \\
10.43 f 0.42\end{array}$ & $\begin{array}{l}14.65-19.65 \\
10.00-10.95\end{array}$ & 100 & $\begin{array}{l}63 \\
63\end{array}$ & $\begin{array}{l}(0.995) \\
(0.907)\end{array}$ & $\begin{array}{l}29 \\
31\end{array}$ & $\begin{array}{l}(0.972) \\
0.984)\end{array}$ & $\begin{array}{ll}57 & 10 \\
60 & 10\end{array}$ & $\begin{array}{l}0.994) \\
0.849)\end{array}$ \\
\hline $\begin{array}{l}\text { IFemoral } \\
\text { ogasawara } \\
\text { ogasawara Is. }\end{array}$ & $\begin{array}{l}0 \\
Q\end{array}$ & $\begin{array}{l}4 \\
4\end{array}$ & $\begin{array}{l}4.76 f 0.69 \\
2.95 \mathrm{f0.13}\end{array}$ & $\begin{array}{l}4.10-5.60 \\
2.00-3.10\end{array}$ & & $\begin{array}{l}701 \\
671\end{array}$ & $(0.894)$ & $\begin{array}{l}351 \\
37\end{array}$ & $\begin{array}{l}0.958) \\
(0.775)\end{array}$ & $\begin{array}{ll}69 & 10 \\
71 & c\end{array}$ & $\begin{array}{l}0.999) \\
0.9231\end{array}$ \\
\hline
\end{tabular}

\section{The praedonia-group}

Diagnosis. Posterior row of eyes slightly wider than anterior row of eyes, lateral eyes somewhat closer than median eyes; fang with an outer cusp near base in both sexes. 


\section{Tetragnatha praedonia L. Koch, 1878}

(Fig. 6, Table 6)

Tetragnatha praedonia L. Koch, 1878, Verh. zool. bot. Ges. Wien, 27 : 744 ; Boesenberg und Strand, 1906, Abh. Senckenbg. Ges., 30 (1-2) : 177 ; Saito, 1933, Trans. Sapporo Nat. Hist. Soc., 13 (1) : 47 ; Saito, 1934, Journ. Agr. Hokkaido Univ., 33 (5) : 335 ; Saito, 1939, Saito Ho-on Kai Mus. Res. Bull., $18: 58$; Yaginuma, 1960, Spiders of Japan in Colour, : 73.

Male. Body length, exclusive of chelicerae 4.8-12.0 mm ; carapacial length 1.8-4.3 $\mathrm{mm}$, width 1.1-2.5 mm ; abdominal length 3.0-7.7 mm, width 1.0-2.2 mm ; cheliceral length 2.0-4.7 mm.

Eyes. Anterior row of eyes occupying full width of head, posterior row of eyes slightly wider than anterior one ; viewed from above, anterior row somewhat strongly recurved, posterior row somewhat gently recurved, so that lateral eyes slightly closer than median eyes.

Chelicerae. Basal segment as long as or slightly longer than carapace, (a) bifid at tip ; (t) and (sl) present, (T) large, (rsu) about 8-10 in number ; (AXl) and (Gl) present, an additional blunt tubercle present on outer side of posterior margin of fang furrow, (rsl) 5-9 in number; fang armed with (EX) near base.

Legs. Leg formula 1. 2. 4. 3 ; all legs with many spines, first femur with 13-21

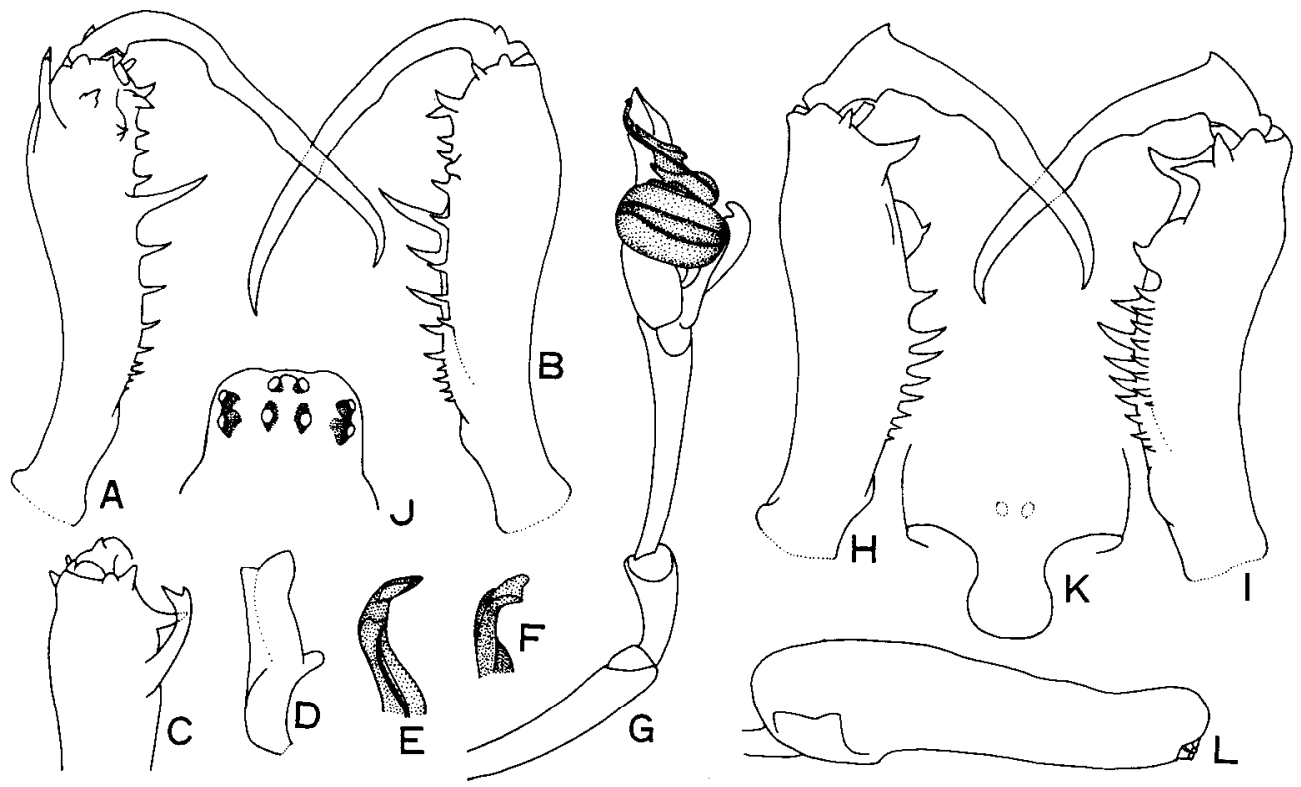

Fig. 6. Tetragnatha praedonia L. Koch. A: Left chelicera of male, upper view. B: Ditto, lower view. C : Ditto lateral view. D : Paracymbium of male. E and F : Distal portion of conductor and embolus of male. $\mathrm{G}$ : Left palpus of male. $\mathrm{H}$ : Left chelicera of female, upper view. I : Ditto, lower view. J : Eye group of male. K : Genital fold of female. L : Abdomen of female, lateral view. 


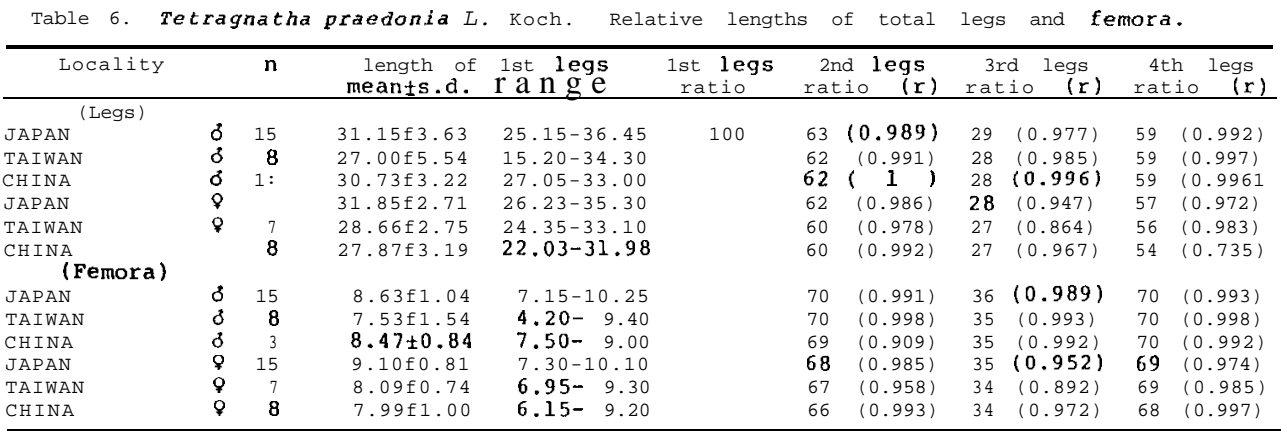

spines; relative lengths of legs as shown in Table 6. $\mathrm{G}$.

Palpi. Paracymbium bifid at tip ; conductor and embolus as shown in Fig. 6, E and

Abdomen. About 3-4 times as long as broad ; distal end of abdomen slightly overhanging spinnerets.

Color in alcohol. Generally light brown to blackish brown; abdomen with indistinct several pairs of dark patches dorsally, and with a central dark gray strip ventrally.

Female. Body length, exclusive of chelicerae 8.2-14 mm ; carapacial length 2.6$3.8 \mathrm{~mm}$, width 1.7-2.4 mm ; abdominal length $5.5-10.5 \mathrm{~mm}$, width 1.7-3.8 mm ; chelicer al length $2.0-3.3 \mathrm{~mm}$.

Eyes. Nearly as in male.

Chelicerae. Basal segment slightly shorter than carapace ; $(\mathrm{AXu})$ present, $(\mathrm{Gu})$ somewhat robust, (e) present, (T) not so large, (rsu) 6-8 in number ; $(\mathrm{AXl})$ present near $(\mathrm{Gl}),(\mathrm{Gl})$ and (AXl) nearly equal in size, (L2) very swollen at base, (rsl) 7-10 in number ; fang robust, armed with (EX) near base.

Legs. Leg formula 1. 2-4. 3 ; all legs with many spines, first femur with 11-20 spines ; relative lengths of legs as shown in Table 6.

Abdomen. About 3-4 times as long as broad; distal end of abdomen slightly overhanging spinnerets; genital fold as shown in Fig. 6, K.

Color in alcohol. Similar to male but abdominal markings more conspicuous than in male.

Specimens examined : Many specimens of both sexes from Japan and Taiwan. This species is one of the commonest spiders in Japan, Taiwan and China.

Distribution : Japan, Korea, Taiwan and China.

\section{The shinanoensis-group}

Diagnosis. Anterior and posterior rows of eyes equal or subequal in width and arranged nearly parallel ; male chelicera with (a), (sl) and (T) ; conductor bifurcated terminally. 
Tetragnatha shinanoensis Okuma and Chikuni, 1978

(Fig. 7, Table 7)

Tetragnatha shinanoensis Okuma and Chikuni, 1978, Acta Arachnol., 28 (1): 1.

Additional specimens :2 우, Amakawa mura, Yoshino Gun, Nara Pref., 20. V. 1979, N. Kikuya ;2 $\sigma^{7}, 1$ 우, Kitayama, Kyoto Pref., 3. VI. 1979, I. Kinoshita ;1 $\Im^{7}, 1$ 우, Miyama machi, Kitakuwata Gun, Kyoto Pref., 24. V. 1980, T. Kamura ; 1 우, Miyama machi, Kitakuwata Gun, Kyoto Pref., 25. V. 1985, T. Kamura.

Distribution : Japan (Honshu).

Note : This species is strikingly different from other known species of Tetragnatha by its bifurcate structure of the male conductor. In this species the pleats on the male conductor is indistinct. Body length of male 5.1-6.0 mm, female 5.9-7.3 mm.

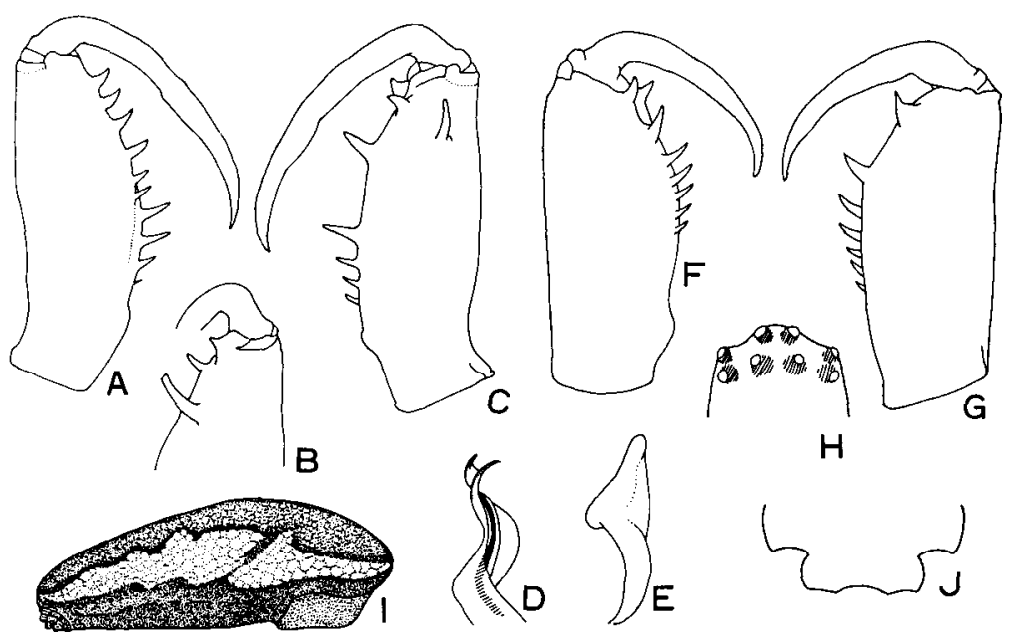

Fig. 7. Tetragnatha shinanoensis Okuma. A : Right chelicera of male, lower view. B : Ditto lateral view. C : Ditto, upper view. D : Distal portion of conductor and embolus of male. E : Paracymbium of male. F : Right chelicera of female, lower view. G : Ditto, upper view. $\mathrm{H}$ : Eye group of female. I : Abdomen of female, lateral view. J : Genital fold of female. (After Okuma, 1978).

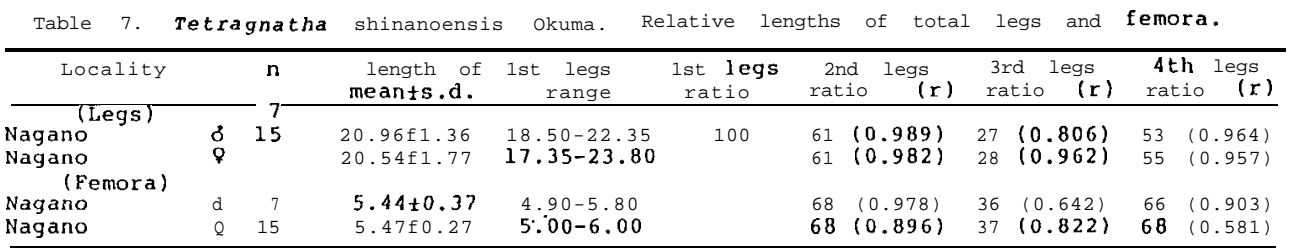

\section{The extensa-group}

Diagnosis. Anterior and posterior rows of eyes subequal in width ; male chelicera with (a), (sl) and (T) ; conductor not bifurcated at tip. 


\section{KEY TO THE SPECIES}

1 Basal segment of male chelicera about 0.8 times as long as carapace ;

(a) bifid at tip

extensa

- Male chelicera about 0.7 times or less as long as carapace pinicola

Tetragnatha extensa (Linnaeus, 1758)

(Fig. 8, Table 8)

Aranea extensa Linnaeus, 1758, Syst. Nat. (10 Ed.), : 621 ; Linnaeus, 1761, Faun. Svec., (2 Ed.) : 489 ;

Fabricius, 1775, Syst. Ent., : 431 ; De Geer, 1783, Mem. p. s. Hist. Ins., 7: 236; Olivier, 1789,

Encycl. Method., 4 : 204.

Aranea solandri Scopoli, 1763, Ent. Cam., : 397.

A ranea mouffeti Scopoli, 1763, Ent. Carn., : 398.

A ranea prima Herrich-Schaffer, 1804, Icon. Ins. Ratisb. Indig., : 49.

A ranea secunda Herrich-Schaffer, 1804, Icon. Ins. Ratisb. Indig., : 49.

Aranea quarta Herrich-Schaffer, 1804, Icon. Ins. Ratisb, Indig., : 49.

Tetragnatha mibra Risso, 1826, Hist. Nat. Princ. Prod. Europ. Merid., : 168.

Tetragnatha extensa : Sundevall, 1832, Vet. Ak. Handl., : 256 ; Hahn, 1834, Die Arachniden, 2 : 43 ; L.

Koch, 1862, Corresp. Bl. Zool. Min. Ver. Regensbg., 16 (5) : 79 ; Westring, 1862, Aran. Svec., : 84 ;

Blackwall, 1864, Hist. Spid. Gr. Brit. Irel,, 2 : 367 ; Keyserling, 1865, Verh. zool. bot. Ges. Wien,

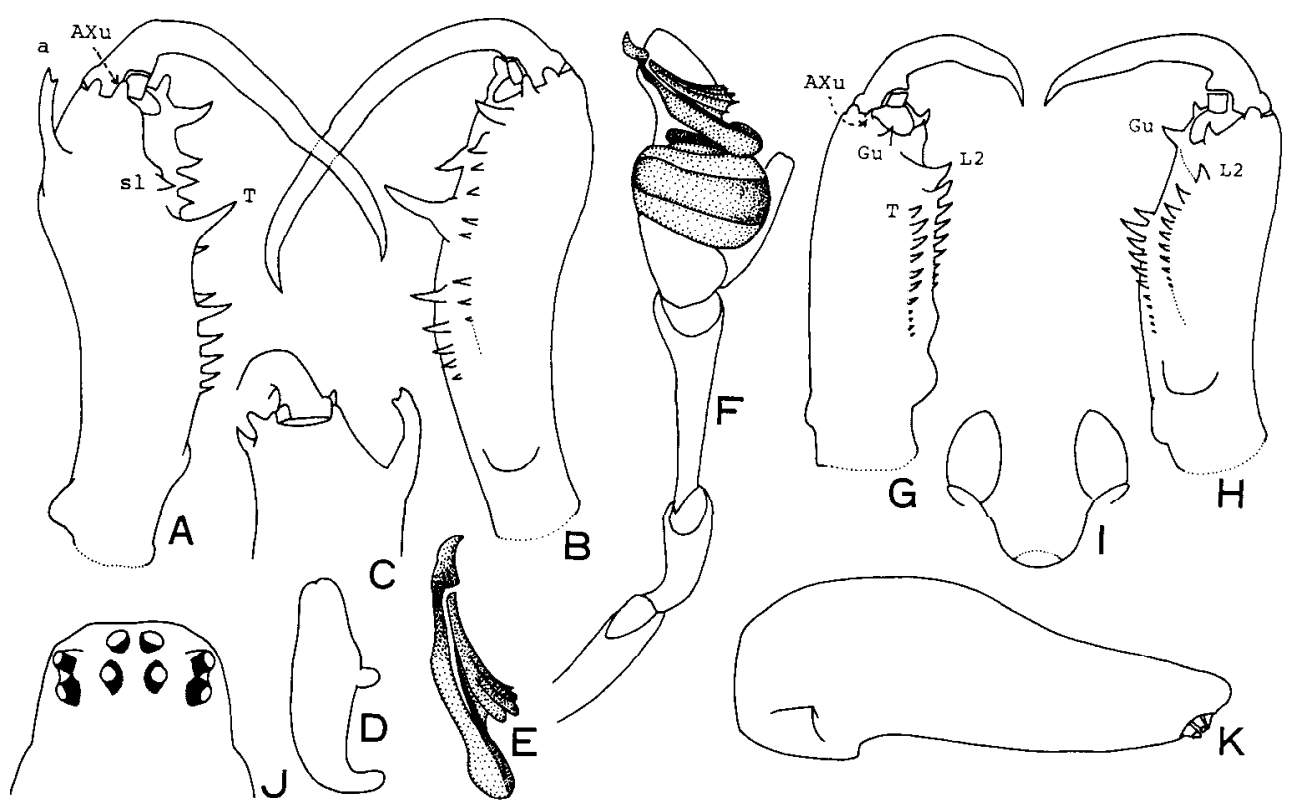

Fig. 8. Tetragnatha extensa (Linne). A : Left chelicera of male, upper view. B : Ditto, lower view. C: Ditto, lateral view. D: Paracymbium of male. E: Conductor and embolus of male. F: Left palpus of male. G: Left chelicera of female, upper inner view. H : Ditto, lower inner view. I : Genital fold of female. J : Eye group of male. $\mathrm{K}$ : Abdomen of female. 


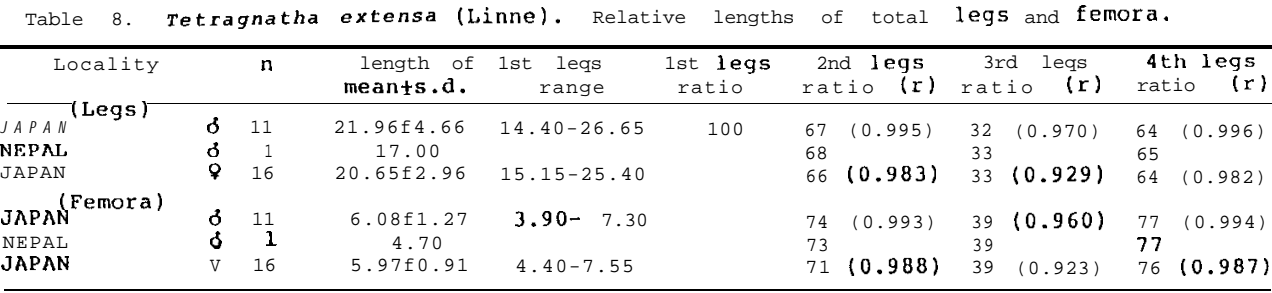

15 : 844 ; Ohlert, 1867, Aran. Prov. Preussen, : 31 ; Thorell, 1875, Proc. Boston Soc. Nat. Hist., 17 : 493 ; Cambridge, 1881, Proc. Dorset F. Cl., 2 : 244 ; Dahl, 1883, Schrift. Nat. Ver. Schlesw. Holst. 5 (2): 32; Emerton, 1884, Trans. Connect. Ac. Sci., 6: 333; Hansen, 1885, Schiodte, 2001. Danica, : 105 ; Chyzer and Kulczynski, 1891, Aran. Hungar., 1: 144 ;McCook, 1893, Amer, Spid., 3: 259; Becker, 1896, Ann. Mus. Nat, Belg., 12 (1): 62; Emerton, 1902, Common Spid.,: 201 ; Kulczynski, 1903, S. B. Ak. Wiss. Wien, 112 (1) : 647 ; Lessert, 1910, Catal. Invert. Suisse ; Araign., : 288 ; Gravely, 1921, Rec. Ind. Mus. Calcutta, 22 (4 ; 24) : 425 ; Seely, 1928, Bull. N. York Stat. Mus., $278: 113$; Simon, 1929, Arachn. de France 6 (3) :648, 651, 749; Wiehle, 1939, Nov. Act. Leopoldina (N.F.), 6 (41) : 376 ; Yaginuma, 1960, Spiders of Japan in Colour : 73.

Tetragnatha gibba C. L. Koch, 1837, Uebers. Arachn. Syst., $1: 5$.

Tetragnatha chrysochlora Walckenaer, 1841, Hist. Nat. Ins. Apt., $2: 215$; Walckenaer, 1847, Hist. Nat. Ins. Apt., $4: 478$.

Tetragnatha versicolor Walckenaer, 1841, Hist. Nat. Ins. Apt., $2: 215$.

Tetragnatha fuviatilis Keyserling, 1865, Verh. zool. bot. Ges. Wien, $15: 852$.

Tetragnatha nowickii L. Koch, 1870, Jahrb. Gel. Ges. Krakau, $41: 13$.

Tetragnatha extensa solandri Boesenberg, 1901, Zoolgica, 13 (1) : 58, 59.

Tetragnatha solandri Lessert, 1910, Catal. Invert. Suisse ; Araign., : 292.

Male. Body length, exclusive of chelicerae 5.1-9.0 mm ; carapacial length 2.0-3.0 $\mathrm{mm}$, width 1.3-2.0 $\mathrm{mm}$; abdominal length 3.1-6.0 mm, width 1.1-1.6 mm ; cheliceral length $1.5-2.5 \mathrm{~mm}$.

Eyes. Anterior row of eyes occupying full width of head, posterior row of eyes slightly wider or narrower than anterior one ; viewed from above, two rows nearly parallel and moderately recurved.

Chelicerae. Basal segment about 0.8 times as long as carapace, (a) bifurcated at tip, $(\mathrm{AXu})$ present, $(\mathrm{Gu})$ absent, (sl) sloping, (T) large, (rsu) 5-6 in number ; $(\mathrm{AXl})$ and (Gl) present, (Gl) somewhat long, (rsl) about 7-8 in number ; fang unarmed.

Legs. Leg formula 1. 2. 4. 3; all legs with spines, first femur with 6-11 spines; relative lengths of legs as shown in Table 8.

Palpi. Tip of paracymbium generally rounded and with small distal notch; conductor and emborus as shown in Fig. 8, E and F.

Abdomen. Moderately long, about 3-4 times as long as broad, not extended posteriorly to spinnerets.

Color in alcohol. Generally light yellowish brown; abdomen with covered by sparse silvery spangles dorsally, somewhat dark brown ventrally.

Female. Body length, exclusive of chelicerae $7.3-12.0 \mathrm{~mm}$; carapacial length 2.6-3.1 mm, width 1.7-2.1 mm ; abdominal length 4.7-9.0 mm, width 1.9-3.4 mm ; cheliceral length $1.7-2.2 \mathrm{~mm}$.

Eyes. Nearly as in male.

Chelicerae. Basal segment about 0.7 times as long as carapace ; $(\mathrm{AXu})$ and $(\mathrm{Gu})$ 
present, (rsu) about 10 in number ; $(\mathrm{AXI})$ absent, (Gl) present (rsl) about 10 in number ; a keel present between $(\mathrm{Gu})$ and (L2) as shown in Fig. 8, $\mathrm{G}$ and $\mathrm{H}$; fang unarmed.

Legs. Nearly as in male ; relative lengths of legs as shown in Table 8.

Abdomen. About 2.5 times as long as broad ; distal end of abdomen not extended posteriorly to spinnerets.

Color in alcohol. Nearly as in male.

Specimens examined : NEPAL : $1 \sigma^{\nearrow}, 2$ ㅇ , Mts. Pir Panjal 2,400 m, Tangmarg, 21. V. 1976, J. Martens. JAPAN : 69 specimens from Hokkaido (Ashoro and Koshimizu Kaen), Aomori (Mt. Hakkoda-san), Iwate (Mt. Hayachine), Tochigi (Nikko), Nagano (Minamiazumi-Gun and Shioziri City).

Distribution : Holoarctic region.

Note: Roberts (1985) remarks as follows: "The sternal patterns separate $\boldsymbol{T}$. extensa and $\boldsymbol{T}$. pinicola from the other species, but it may sometimes be difficult to distinguish between small or immature females of $\boldsymbol{T}$. extensa and adult females of $\boldsymbol{T}$. pinicola. This problem is reliably overcome by measuring the ratio of femur I width/ femur III length. This is greater than 0.205 in females of $\boldsymbol{T}$. extensa (adult and subadult) and less than 0.176 in $\boldsymbol{T}$. pinicola".

Tetragnatha pinicola L. Koch, 1870

(Fig. 9, Table 9)

Tetragnatha pinicola L. Koch, 1870, Jahrb. Gel. Ges. Krakau, 41 : 11 ; Dahl, 1883, Scharift. Nat. Ver.

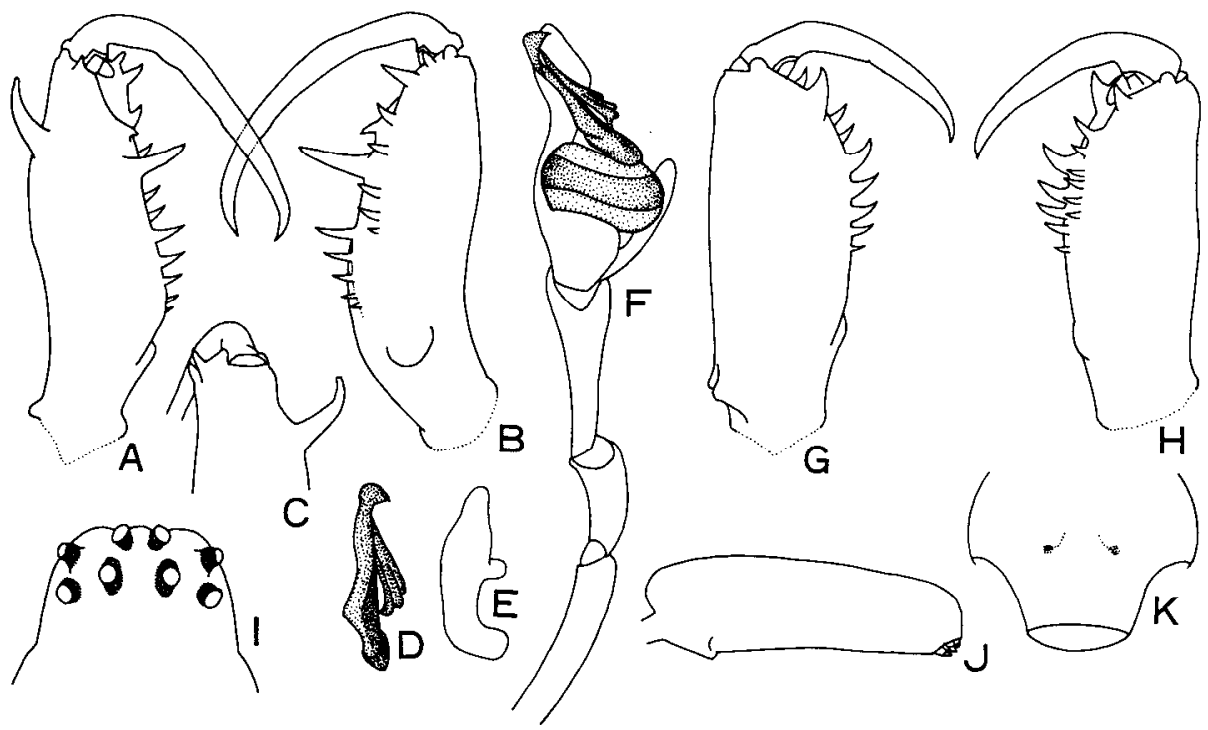

Fig. 9. Tetragnatha pinicola L. Koch. A : Left chelicera of male, upper view. B : Ditto, lower view. C : Ditto, lateral view. D : Conductor and embolus of male. E : Paracymbium of male. F : Left palpus of male. G : Left chelicera of female, upper view. H : Ditto, lower view. I: Eye group of male. J: Abdomen of male, lateral view. K: Genital fold of female. 


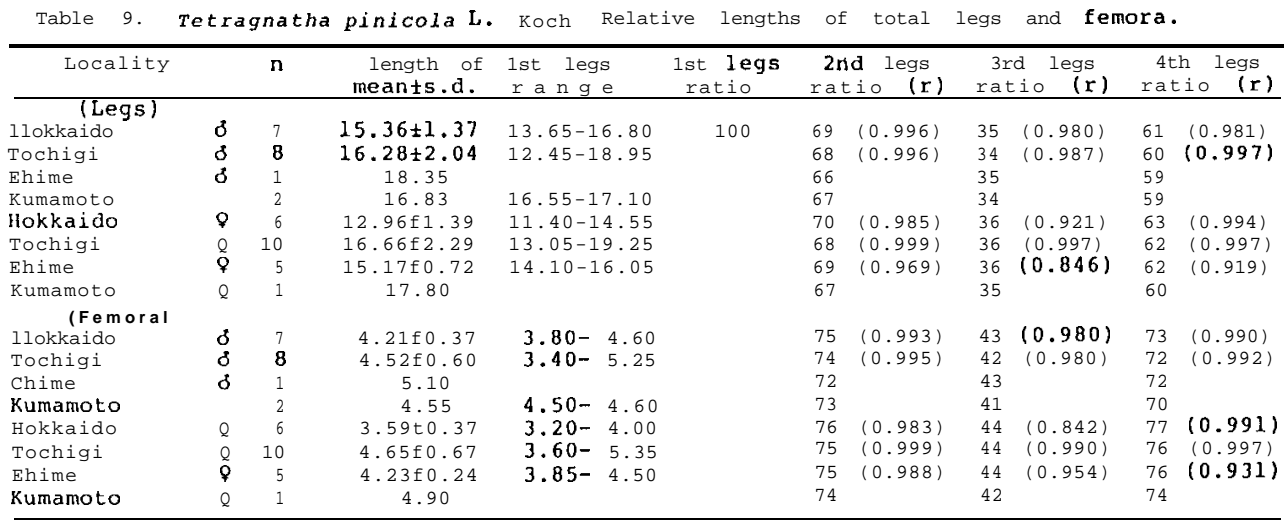

Schlew. Holst., 5 (2) : 33 ; Chyzer and Kulczynski, 1891, Aran. Hungar., 1 : 144 ; Boesenberg, 1901, Zoologica, 13 (1) : 61 ; Kulczynski, 1903, S. B. Ak. Wiss. Wien, 112 (1) : 647; Lessert, 1910, Catal. Invert. Suisse ; Araign ., : 291; Simon, 1929, Arachn, de France, 6 (3) : 651, 749 ; Wiehle, 1939, Nov. Act. Leopoldina (N. F.), 6 (41) : 376; Yaginuma, 1960, Spiders of Japan in Colour : 73. Eugnatha picta Lendl, 1886, Math. Term. Kozlem., $22: 129$.

Male. Body length, exclusive of chelicerae 4.1-8.2 mm ; carapacial length 1.5-2.2 $\mathrm{mm}$, width 1.0-1.4 mm ; abdominal length 2.5-6.0 mm, width 0.9-2.1 mm ; cheliceral length 1.1-1.4 mm.

Eyes. Anterior row of eyes occupying full width of head, posterior row of eyes slightly wider or narrower than anterior one ; viewed from above, two rows nearly parallel and moderately recurved.

Chelicerae. Basal segment about 0.7 times as long as carapace, (a) not bifid at tip, $(\mathrm{AXu})$ present, $(\mathrm{Gu})$ absent, (sl) sloping, (T) large ,(rsu) about 5 in number ; $(\mathrm{AXl})$ and (Gl) present, (rsl) about 5 in number; fang unarmed.

Legs. Leg formula 1. 2. 4. 3; all legs with spines, first femur with 5-7 spines; relative lengths of legs as shown in Table 9.

Palpi. Paracymbium bluntly rounded at tip; distal end of conductor bird's head-like and somewhat twisted as shown in Fig. 9, E and F.

Abdomen. About 3 times as long as broad ; distal end of abdomen not extended posteriorly to spinnerets.

Color in alcohol. Generally light yellowish brown; dorsum of abdomen with covered by silvery spangles and with several pairs of small black dots along central line, venter somewhat dark brown.

Female. Body length, exclusive of chelicerae 6.4-9.5 mm ; carapacial length 1.9$2.6 \mathrm{~mm}$, width $1.2-1.6 \mathrm{~mm}$; abdominal length $4.5-6.9 \mathrm{~mm}$, width $1.8-2.5 \mathrm{~mm}$; cheliceral length $1.0-1.7 \mathrm{~mm}$.

Eyes. Nearly as in male.

Chelicerae. Basal segment 0.5-0.7 times as long as carapace ; without particular features.

Legs. Nearly as in male ; relative lengths of legs as shown in Table 9.

Abdomen. About 2.5 times as long as broad ; distal end of abdomen not extended posteriorly to spinnerets.

Color in alcohol. Nearly as in male, but abdominal small black dots often absent. 
Specimens examined : JAPAN : 113 specimens from Hokkaido (Nukabira and Ashoro), Tochigi (Nikko), Gifu (Mt. Shin-hodaka-San), Ehime (Mt. Ishizuchi-san), Kumamoto (Mt. Shiratori-yama).

Distribution : Palaearctic Region. 